\title{
Seed structure and initial development of Byrsonima basiloba Juss. (Malpighiaceae)
}

\section{Estructura de la semilla y desarrollo inicial de Byrsonima basiloba Juss. (Malpighiaceae)}

\author{
Conceição Eneida dos Santos Silveira, Dario Palhares*, Karina Barros, Damasceno Pereira, \\ Zanderluce Gomes luís \& Luiz Alfredo Rodrigues Pereira
}

Universidade de Brasília, Instituto de Biologia, Departamento de Botânica, Laboratório de Anatomia Vegetal. Campus Universitário Darcy Ribeiro, Asa Norte, CEP 70910-900, Brasília, DF, Brazil.

*dariompm@unb.br

\begin{abstract}
Byrsonima basiloba Juss. is a fast growing shrub that produces edible and juicy fruits. This research studied the morphology and anatomy of seeds and seedlings. The hard endocarp was crested and triloculate, with one seed per locule. B. basiloba seed was composed of a testa and a tegmen with residual endosperm. The embryo was ivory, with long, foliaceous, circinate, anisophyllous cotyledons with disjointed apices. The embryonary axis was short, straight and occupied a small portion of the seed with short epicotyl, and radicle with a rudimentary root cap. In the seedlings, it was possible to differentiate the protoderm, procambium and ground meristem in the elongation zone. The differentiation process in this species occurred early in the embryo. Leaf primordia surrounded the shoot apical meristem, which contained a developing parenchyma, epidermis with trichomes, and the vascular system already partially differentiated, with xylem vessels with helical thickening. The stem/root transition region, which originated the xylopodium in the adult plant, was oblique to the stem axis. Cotyledons and eophylls were amphistomatic. The anatomical description can help with taxonomic identification of the species in the field, as well as to provide a guide to choosing explants for in vitro cultivation protocols.
\end{abstract}

KEYwords: Seedling, cotyledons, endocarp, amphistomy, Cerrado.

\section{RESUMEN}

Byrsonima basiloba Juss. es un arbusto de rápido crecimiento que produce frutos comestibles y jugosos. Esta investigación estudió la morfología y anatomía de las semillas y plantas jóvenes de este arbusto. Su endocarpio duro contiene una semilla por lóculo. La semilla está compuesta por una testa y un tegumento con un endospermo residual. El embrión es de color marfil, con cotiledones largos circinados, anisófilos, foliáceas con ápices inconexos. El eje embrionario es corto, recto, con epicotilo corto y radícula, y con una tapa de raíz rudimentaria, y ocupa una pequeña porción de la semilla. En la plántula es posible diferenciar claramente la protoderma del procambium y del meristema primario. Inmediatamente por encima del promeristema se encuentran el parénquima cortical, la epidermis con pelo, y el cilindro vascular ya parcialmente diferenciado, así como los vasos del xilema con engrosamiento helicoidal, por lo que se puede concluir que la diferenciación de los tejidos de esta especie se produce muy temprano. La región de cuello, que se origina del xilopodium en la planta adulta, no muestra ningún cambio en el color, siendo oblicua al eje del vástago. Los cotiledones y eófilos son anfistomáticos. La descripción anatómica puede ayudar con la identificación taxonómica de las especies, como también proporcionar una guía para el futuro, en cuanto a protocolos de cultivo in vitro.

Palabras ClaVe: Plántula, cotiledón, endocarpo, anfiestomático, Cerrado.

\section{INTRODUCTION}

In the Cerrado biome, about 38 species (commonly known as "murici") have been registered in the Byrsonima. They have economic potential due to their edible fruits, cork production, recuperation of degraded areas purposes, medicinal properties as well as ornamental to be used in gardens and parks. In addition, Byrsonima plants usually produce nectar, oils, and are frequently visited by bees for pollination. Byrsonima basiloba Juss. (Malpighiaceae) is a shrub of rapid growth that produces one of the largest fruits of the genus. Hence, this species has been targeted for 
domestication and cultivation (Almeida et al. 1998), and in vitro propagation protocols for murici have been carried out by Silva et al. (2012) and Martendal et al. (2013).

Concerning the structural features of Byrsonima genus, Barros (1992) and Barroso et al. (1999) investigated the morpho-anatomy of fruit and seeds from several species. However, post-seminal anatomical studies of seedlings and young plants are rare of this genus in the literature. This kind of investigation is highly significant as the characterization of seedlings and young plants can be used for field identification and establishing parameters to assess the quality of micropropagated plants. The knowledge on this topic is crucial because it has been determined that in vitro conditions can generate anatomical changes that may significantly reduce the viability of the plants.

The morphology of initial phases of the post-seminal development of B. basiloba and other species were described by Silveira et al. (2013a, b). Thus, the present work is a study of $B$. basiloba seed anatomical structure and twomonth-old seedlings. At this age, the stem and root system has expanded and can be differentiated from one another.

\section{MATERIAL AND METHODS}

Mature fruits from five mother plants of Byrsonima basiloba were collected in Brasilia-DF in the following coordinates: S $15^{\circ} 28^{\prime} \mathrm{W} 47^{\circ} 30^{\prime}, \mathrm{S} 15^{\circ} 44^{\prime} \mathrm{W} 47^{\circ} 52^{\prime}, \mathrm{S}$ $15^{\circ} 37^{\prime} \mathrm{W} 47^{\circ} 44^{\prime}$. Voucher specimens were deposited in the UB Herbarium (University of Brasilia) under registration numbers UB 10623, UB 11690, UB 11692, UB 11694, and UB 11695. The fruit was depulped under tap water, and for removal of the pulp remnants, it was put in the pathways of small domestic ants that removed all the remaining pulp within a few days. The morphological and anatomical study of the endocarp and the seeds was done by analyzing 15 endocarps and 15 seeds. The nomenclature used is based on the works of Barroso et al. (1999), Oliveira (2001), and Souza et al. (2009). The seedlings were obtained from seeds removed and then germinated in cups containing sand at room temperature, as described in Silveira et al. (2013b). Ten healthy seedlings of two months old were processed for anatomical analysis. This work considered seedlings as individuals formed from the germination of the seed until the complete expansion of the first two pairs of eophylls (Duke 1965, Souza et al. 2009).

For the anatomical study, dissociated material was obtained by treating the samples with Jeffrey's solution. Additionally, the endocarps were cooked in an autoclave (1 atm of pressure at $120^{\circ} \mathrm{C}$ for $12 \mathrm{~h}$ ). Moreover, the plant material was fixed in FAA-50, dehydrated in an alcoholic series, and then embedded in either paraffin or Historesin, Leica. Transverse sections of 10 to $15 \mu \mathrm{m}$ were obtained on a rotatory microtome, and the ribbons were expanded on microscopy slides, dewaxed, and then stained with fast green and safranin.

Hand sections were obtained on table microtome and tested for the presence of starch (Lugol), lipids (Sudan III), phenolic compound (Iron Chlorine), protein (Xylidine Ponceau), and polysaccharides (Schiff's periodic acid) (Johansen 1940).

\section{RESULTS}

\section{Fruit AND SEED}

Byrsonima basiloba fruit ripening started from bottom to top and took approximately four months to complete. The fruit was drupoid, depressed-globose with a three-layered pericarp containing (a) a thin and yellow exocarp; (b) 8 mm thick yellow mesocarp; and (c) an extremely sclerified endocarp. The endocarp (Fig. 1-3) had the same shape as the fruit, was brown, trilocular, woody, crested and measured about $13.40 \mathrm{~mm}( \pm 1.24)$ wide, $10.15 \mathrm{~mm}( \pm 1.16)$ long. Moreover, it had one seed per loculus, and therefore, was classified as a pyrene. Nonetheless, rarely all seeds were viable; most frequently, there was only one well-developed seed per fruit. The upper portion of the endocarp had a large suture with the shape of a three-pointed star, and at the bottom, there was a concavity where the pedicel was inserted. Anatomically, the endocarp was exclusively composed of irregularly arranged sclerified cells (Fig. 2) with large lumens. The dissociated material revealed the occurrence of sclereids, mostly brachio-sclereids and macrosclereids, as well as some fibers.

The seed shape was subglobose to angular, piriform, about $5 \mathrm{~mm}( \pm 0.26)$ wide, and occupied the whole internal space of the endocarp loculus (Fig. 3). The tegument was membranaceous, smooth, and brown. B. basiloba embryo was ivory-colored, with long, foliaceous, circinate, anisophyllous cotyledons, which had disjointed apices (Fig. 4). The embryonary axis was short, straight, and occupied a small part of the seed (Fig. 4-5).

The epicotyl was extremely short with an undifferentiated five-cell layered plumule whose cells had a dense cytoplasm and conspicuous nuclei (Fig. 6). The apical region of the hypocotyl-root axis had a rudimentary root cap, which covers the root promeristem (Fig. 7-9). The embryo protoderm was uniseriate with cells dividing anticlinally. The ground meristem, both in the cortical and pith regions, was composed of cells with an incipient vacuolization. The procambium was composed of elongated cells with conspicuous nuclei throughout the embryo. In general, meristematic cells of both shoot and root meristems presented large nuclei and dense cytoplasm with abundant granules, most likely protein bodies. Histochemical tests detected the presence of lipids and proteins in embryo cells.

The cotyledons had a uniseriate epidermis consisted 
of cuboidal cells with rounded corners (Fig. 10-11). Differentiating stomata were observed in the epidermis. In the middle region of the cotyledon, the mesophyll was eight to nine cells wide. The first subepidermal layer (on the adaxial side) was palisade, with cells dividing periclinally. The remaining cell layers were formed by compact isodiametric cells. Histochemical tests showed large amounts of lipids and proteins on both adaxial and abaxial faces as well as in the mesophyll cells. No starch was detected in the embryo.

The seed coat was composed of two parts as following: a) the outer layer was the testa, and, b) the inner layer was the tegmen (Fig. 12-13). Moreover, internally to the tegmen a residual endosperm up to four cells long could be identified close to the embryo apex (Fig. 4-5). Furthermore, lipid and protein bodies were observed in the endosperm cells, as well as the presence of polysaccharide in the cell walls. Starch was not detected in these cells.

\section{SEEDLINGS AND YOUNG PLANTS}

Byrsonima basiloba seeds were germinated in vitro to facilitate data collection and presented an epigeous germination (Fig. 14). One-two days after inoculation the seeds were fully imbibed, and the tegument started to break. Subsequently, the cotyledons began to unwind, and the radicle began to elongate. Besides, between 5-8 days after inoculation, the cotyledons turned greenish. Around the $20^{\text {th }}$ day, the cotyledons were oblong, dark green, with decurrent opposite basis, symmetrical, and foliaceous. The pivoting root was thick and grew straight and at this stage, the lateral roots had already been developed (Fig. 15).

Around the $30^{\text {th }}$ day of cultivation, when the first eophylls appeared, the expansion of the epicotyl became noticeable, and the first pair of eophylls was produced. After 45 days, the young plant showed an epicotyl with pale green young leaves (Fig. 14), with trichomes on both surfaces.

After two months, the plant was approximately $8 \mathrm{~cm}$ long, from which $5 \mathrm{~cm}$ composed the root system, and 3 $\mathrm{cm}$ the shoot with 2 to 4 pairs of eophylls (Fig. 14). The root system was axial with lateral roots (Fig. 15). The connection between the main root and the hypocotyl was oblique to the stem axis (Fig. 15). The basis of the hypocotyl was thickened, which corresponded to the initial phase of xylopodium differentiation (Fig. 15). The cotyledons were, morphologically opposite, oblong, fleshy-membranous, with visible midrib, glabrous, with the ventral face greener than the dorsal face. The eophylls showed intrapetiolar stipules and a cross opposite phyllotaxy, which was perpendicular to the cotyledons. The shoot internodes were covered by whitish trichomes, typical of the family, which are named Malpighiaceae trichome. The apical bud was densely hairy and visible before the completion elongation of the eophylls.
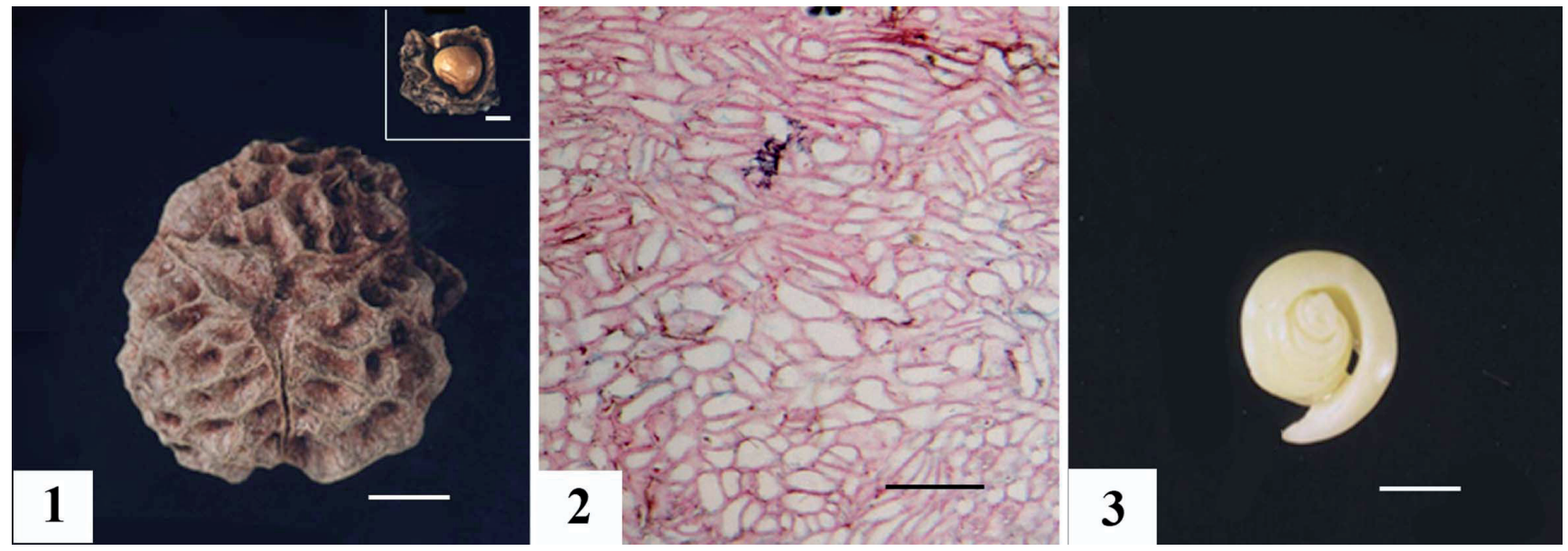

Figures 1-3. Morpho-anatomical aspects of Byrsonima basiloba fruit. 1. View of the endocarp showing three-point star scar. Inset: seed within the brownish endocarp. 2. Section of the endocarp showing sclerified cells with large lumens and lignified walls. This structure is consistent with mechanical resistance, lightness and thermal isolation. 3. Morphological aspect of the embryo with circinate cotyledons. Scale bars: 1 and $3=0.2 \mathrm{~cm} ; 2=180 \mu \mathrm{m}$.

Figuras 1-3. Aspectos morfo-anatómicos de Byrsonima basiloba fruto. 1. Vista del endocarpio mostrando una cicatriz en forma de estrella de tres puntas. Recuadro: las semillas dentro del endocarpio de color marrón. 2. La sección del endocarpio que muestra células esclerificadas con grandes lúmenes y paredes lignificadas. Esta estructura es coherente con la resistencia mecánica, ligereza y de aislamiento térmico. 3. Aspecto morfológico del embrión con los cotiledones circinados. La barra de escala: 1 y $3=0,2 \mathrm{~cm} ; 2=180 \mu \mathrm{m}$. 


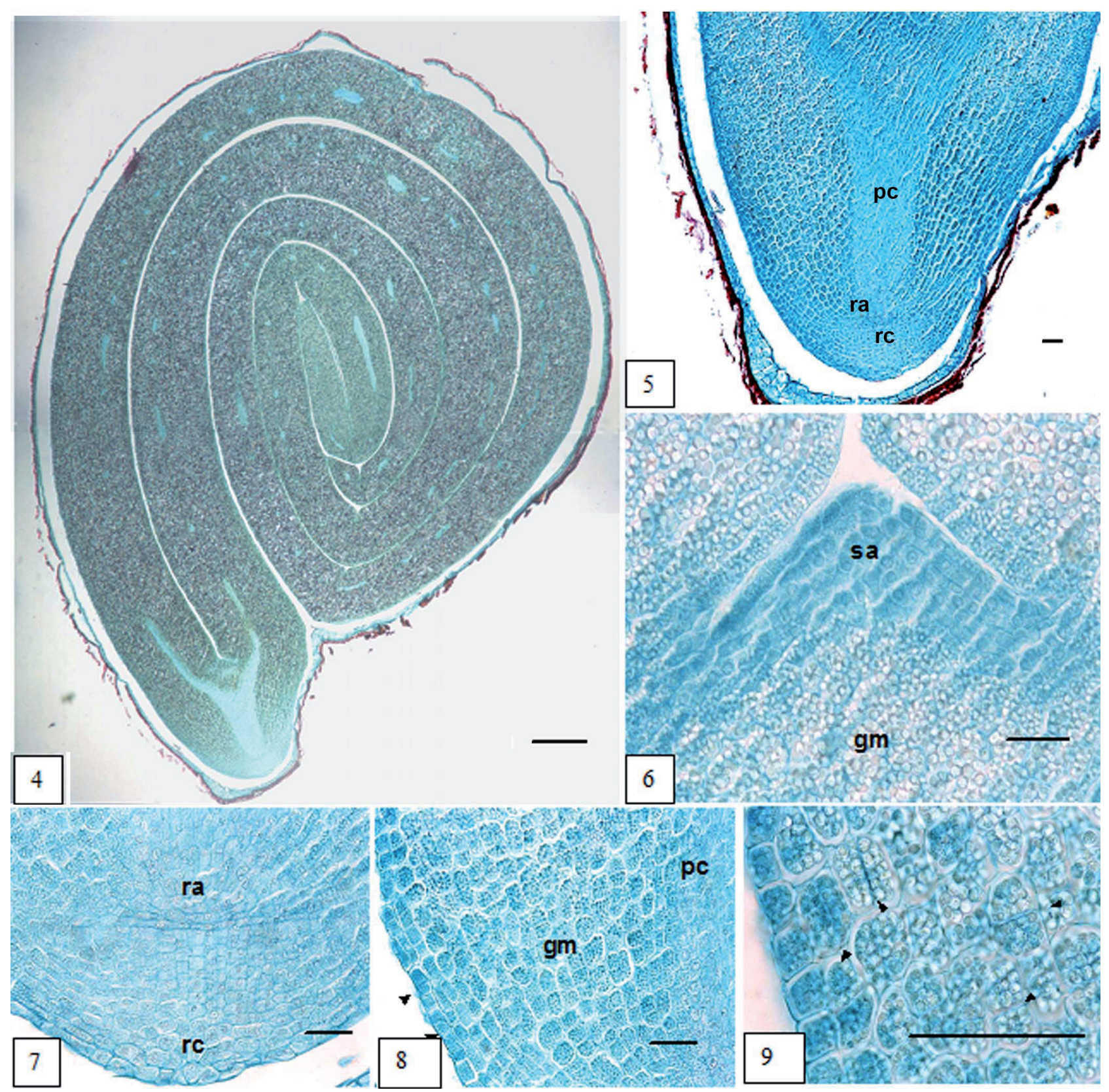

Figures 4-9. Anatomical aspect of Byrsonima basiloba embryo. 4. Seed showing circinate cotyledons with disjoint apex and placed in the central region and a short straight embryonic axis. 5. General aspect of embryonary axis. 6. Detail of the shoot apex with cells with dense cytoplasm and conspicuous nuclei. 7. Detail of root cap cells in differentiation. 8. Detail of the protoderm with cells in anticlinal division (arrowheads), ground meristem with isodiametric cells and procambium with elongated cells. 9. Detail of ground meristem with cells in periclinal and anticlinal division (arrowheads) and a great amount of reserve granules. gm: ground meristem; pc: procambium; ra: root apex; rc: root cap; sa: shoot apex. Scale bars $=50 \mu \mathrm{m}$.

Figuras 4-9. Aspecto anatómico del embrión de Byrsonima basiloba. 4. Semilla colocada en la región central, que muestra cotiledones circinados con ápices disjuntos, y un eje embrionario recto y corto. 5. Aspecto general del eje embrionario. 6. Detalle del ápice caulinar con células de citoplasma denso y núcleos conspicuos. 7. Detalle de las células de la raíz campana en la diferenciación. 8. Detalle de la protoderm con células en división anticlinale (puntas de flecha): meristemo cortical primario con células isodiamétricas y procambium con células alargadas. 9. Detalle de meristema cortical primario con células en división periclinal y anticlinal (puntas de flecha) y con una gran cantidad de gránulos de yacimientos. gm: meristema fundamental; ra: meristemo apical de la raíz; rc: raíz campana; pc: procambium; sa: meristemo apical del tallo. La barra de escala $=50 \mu \mathrm{m}$. 

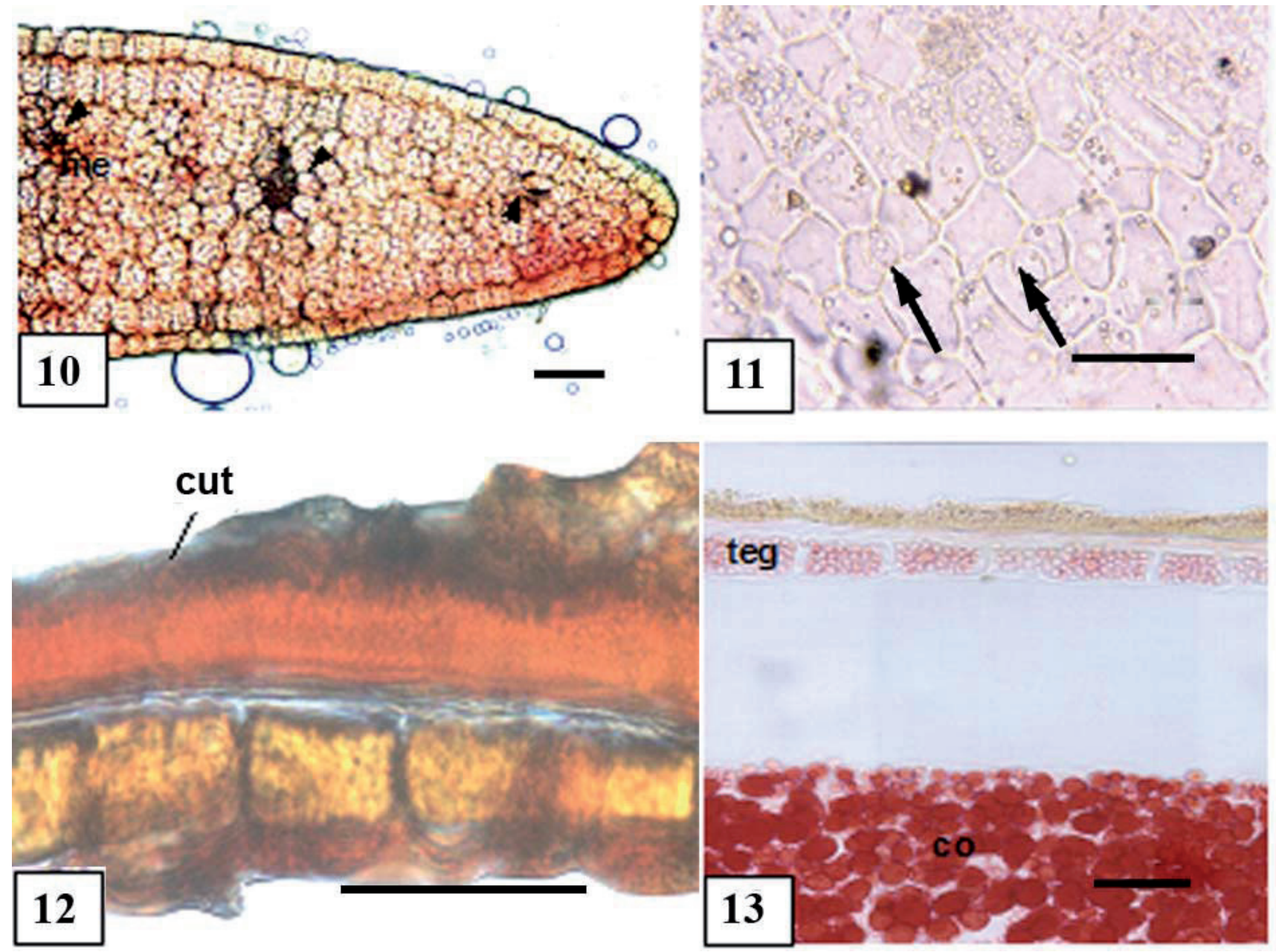

Figures 10-13. Anatomical aspects of cotyledons before the germination as well as the seed coat. 10. General aspect in croos section showing the epidermis, mesophyll, vascular bundles (arrowheads) and abundance of reserve globules. 11. Paradermal section showing epidermal cells of different shapes and straight or slightly waved anticlinal walls. Stomatal apparatus in differentiation, with guard cells in differentiation (arrows). 12. Tegument cross section reacted with Sudan III showing the cuticle and tabular cells containing lipid substances with thicker external periclinal wall. 13. Longitudinal section of the seed showing the seed coat and part of the cotyledon after reaction with Ponceau Xylidine and showing cotyledonary protein globules. co: cotyledon; cut: cuticle; me: mesophyll; teg: tegument. Scale bars $=50 \mu \mathrm{m}$.

Figuras 10-13. Aspectos anatómicos de los cotiledones antes de la germinación, así como la cubierta de la semilla. 10. Aspecto general en la sección transversal que muestra la epidermis, mesófilo, haces vasculares (puntas de flecha) y la abundancia de glóbulos de reserva. 11. Paradermal sección que muestra células epidérmicas de diferentes formas con paredes anticlinales rectas y ligeramente onduladas. Aparato de estomas en la diferenciación, con células de guarda en la diferenciación (flechas). 12. Sección transversal tegumento reaccionó con Sudán III muestra la cutícula y las células tabulares contienen sustancias lipídicas con la pared periclinal externa más gruesa. 13. Sección longitudinal de la semilla que muestra la cubierta de la semilla y parte de los cotiledones después de la reacción con Xilidina Ponceau mostrando glóbulos de proteína de cotiledones. co: cotiledón; cut: cuticula; me: mesófilo; teg: tegumento. La barra de escala $=50 \mu \mathrm{m}$. 


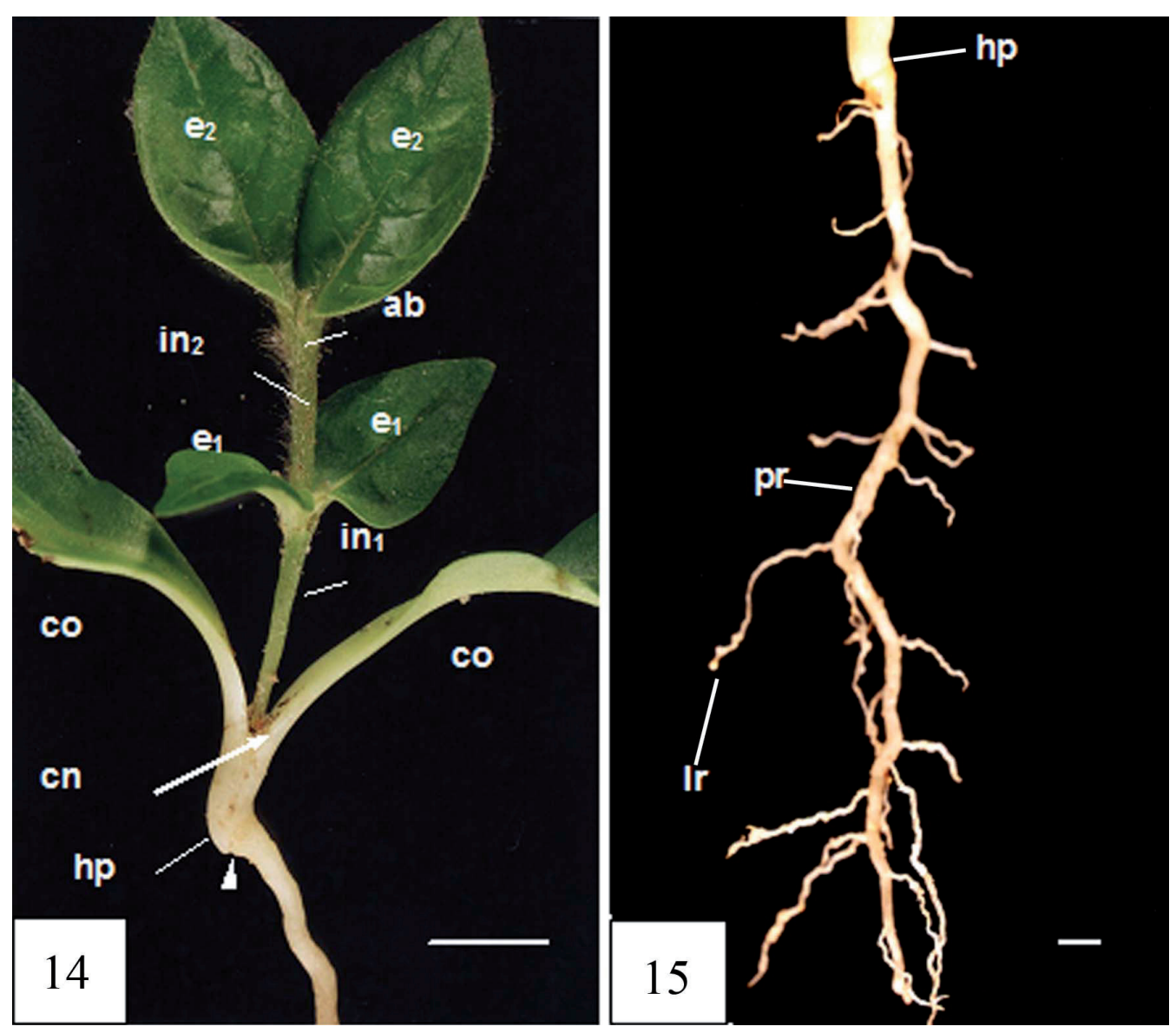

Figures 14-15. Morphological aspect of two-month old Byrsonima basiloba seedling. 14. General view. Shoot, insertion of cotyledons (arrow), hypocotyl and beginning of principal root (arrowhead). 15. Root system showing the principal root and lateral roots. ab: apical bud; cn: cotyledonary node; co: cotyledons; e1: first pair of eophylls; e2: second pair of eophylls; in1: first internode; in2: second internode; hp: hypocotyl; lr: lateral root; pr: principal root. Scale bars $=0.5 \mathrm{~cm}$.

Figuras 14-15. Aspecto morfológico de plántulas de Byrsonima basiloba de dos meses de edad. 14. Vista general del tallo, la inserción de los cotiledones (flecha), hipocotilo y principios de la raíz principal (punta de flecha). 15. Sistema de la raíz que muestra la raíz principal y de raíces laterales. ab: yema apical; cn: nodo cotiledonar; co: cotiledones; e1: primer par de eofilos; e2: segundo par de eofilos; in1: primero del entrenudo; in2: segundo del entrenudo; hp: hipocotilo; lr: raíz lateral; pr: raíz principal. La barra de escala $=0,5 \mathrm{~cm}$.

The main root (Fig. 16-22) presented a reduced root cap (average length $110 \mu \mathrm{m}$ ) and was made of a conical arrangement of cells in different stages of differentiation. The meristematic region was short in average $70 \mu \mathrm{m}$ long. The promeristem was made of approximately three layers of cells, anticlinally elongated, and each layer presenting four to five cells (Fig. 16-18). The protoderm, as well as the ground meristem, and the procambium were clearly differentiated from the promeristem, which was composed of few cells (Fig. 16-18). Above the meristematic region, the cortical parenchyma and vascular cylinder were already differentiated. In the procambium, protoxylem vessels with helical thickening distant from the promeristem about two to three layers of cells (Fig. 19-22). The vascular system was tetrarch with one cell layered pericycle (Fig. 19-20).
Metaxylem vessels started maturing $2 \mathrm{~cm}$ above the root apex. The cortex was composed of seven to nine layers of cells with a uniseriate endodermis. In the outer cortex region, there was an exodermis whose cells were slightly smaller than the cortical parenchyma (Fig. 21). The epidermis was uniseriate and made of tabular cells with abundant trichomes (Fig. 22).

In mature regions of the root, the central portion of the vascular system presented cells with lignified walls. The vascular cambium was already differentiated and produced secondary xylem between the bundles of primary xylem (Fig. 23-24). At this stage, the cortex kept an intact endodermis, which was discontinued in the regions where lateral roots developed (Fig. 24). The epidermis had a high density of trichomes. 


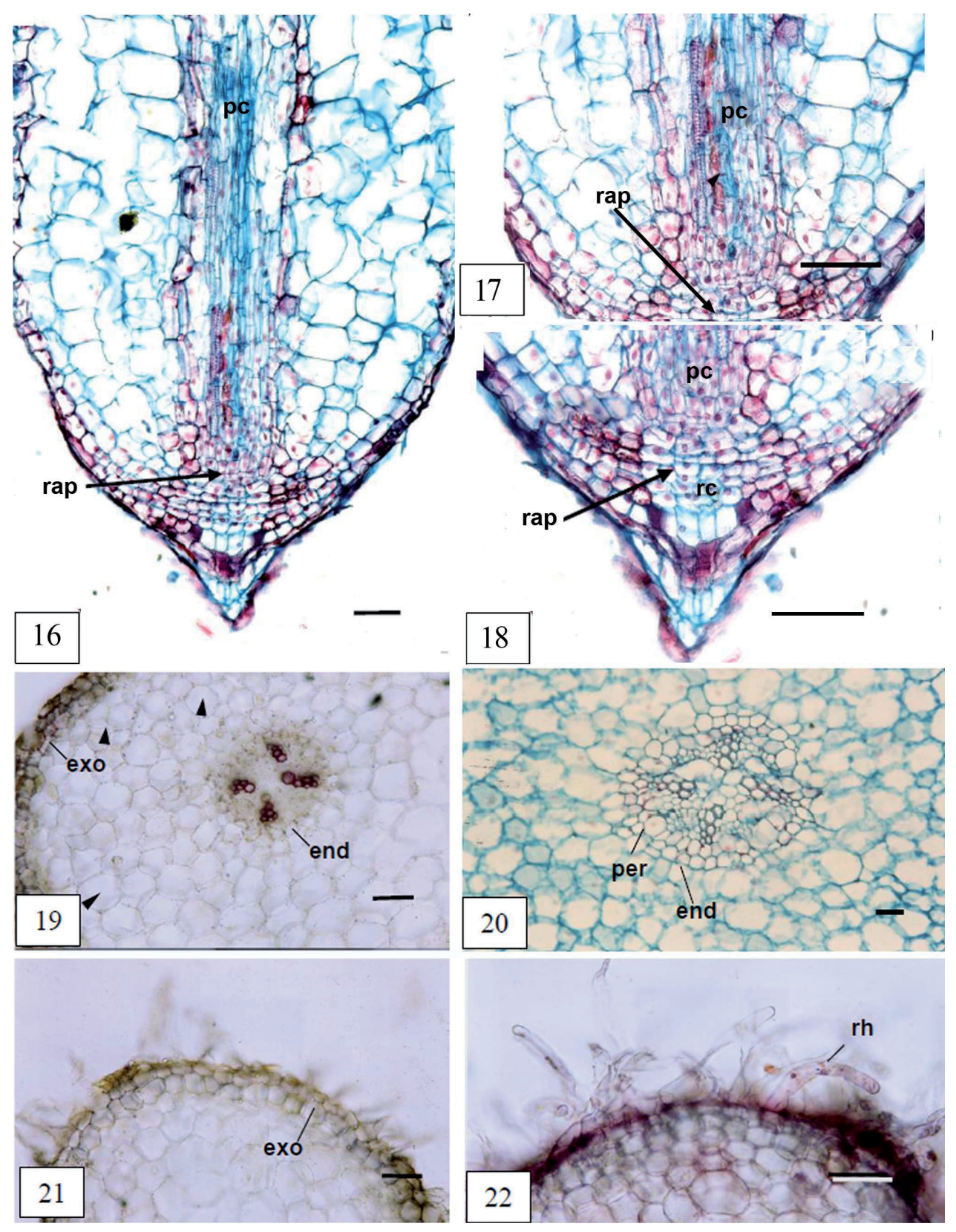

Figures 16-22. Anatomical aspects of the principal root of the seedling of Byrsonima basiloba. 16. General aspect of the root apex showing. 17. Detail of the ground meristem, protoderm and procambium, with vessel element with secondary helical thickening. 18. Detail of cells of root apex and root cap. 19. General aspect at $0.4 \mathrm{~cm}$ above the apex showing the organization of vascular cylinder and cortex. 20. Detail of the vascular cylinder at $2 \mathrm{~cm}$ above the apex with four poles of protoxylem with only one metaxylem vessel per pole; primary phloem between the poles; pericycle with radially elongated cells. 21 . Detail of the cortex at $0.4 \mathrm{~cm}$ above the apex showing the exodermis underneath the epidermis. 22. Detail of the epidermis at $0.4 \mathrm{~cm}$ above the apex, showing long trichomes. end: endodermis; exo: exodermis; pc: procambium; per: pericycle; rap: root apical meristem; rc: root cap; rh: root hair. Scale bars $=50 \mu \mathrm{m}$.

Figuras 16-22. Aspectos anatómicos de la raíz principal de la plántula de Byrsonima basiloba. 16. Aspecto general del ápice de la raíz. 17. Detalle de los meristemos fundamental, protoderm y procambium con el elemento de vaso con engrosamiento helicoidal secundario. 18. Detalle de las células del ápice de la raíz y la capucha de la raíz. 19. Aspecto general a $0,4 \mathrm{~cm}$ por encima del vértice que muestra la organización del cilindro vascular y la corteza. 20. Detalle del cilindro vascular a $2 \mathrm{~cm}$ por encima del ápice con cuatro polos de protoxilema con una sola célula de metaxilema por polo; floema primario entre los polos; periciclo con células alargadas radialmente. 21. Detalle de la corteza a $0,4 \mathrm{~cm}$ por encima del ápice que muestra los exodermis debajo de la epidermis. 22 . Detalle de la epidermis a $0,4 \mathrm{~cm}$ por encima del ápice, mostrando tricomas largos. end: endodermo; exo: exodermo; per: periciclo; pc: procambium; rap: meristemo apical de la raíz; rc: cofia; rh: pelo radicular. La barra de escala $=50 \mu \mathrm{m}$. 


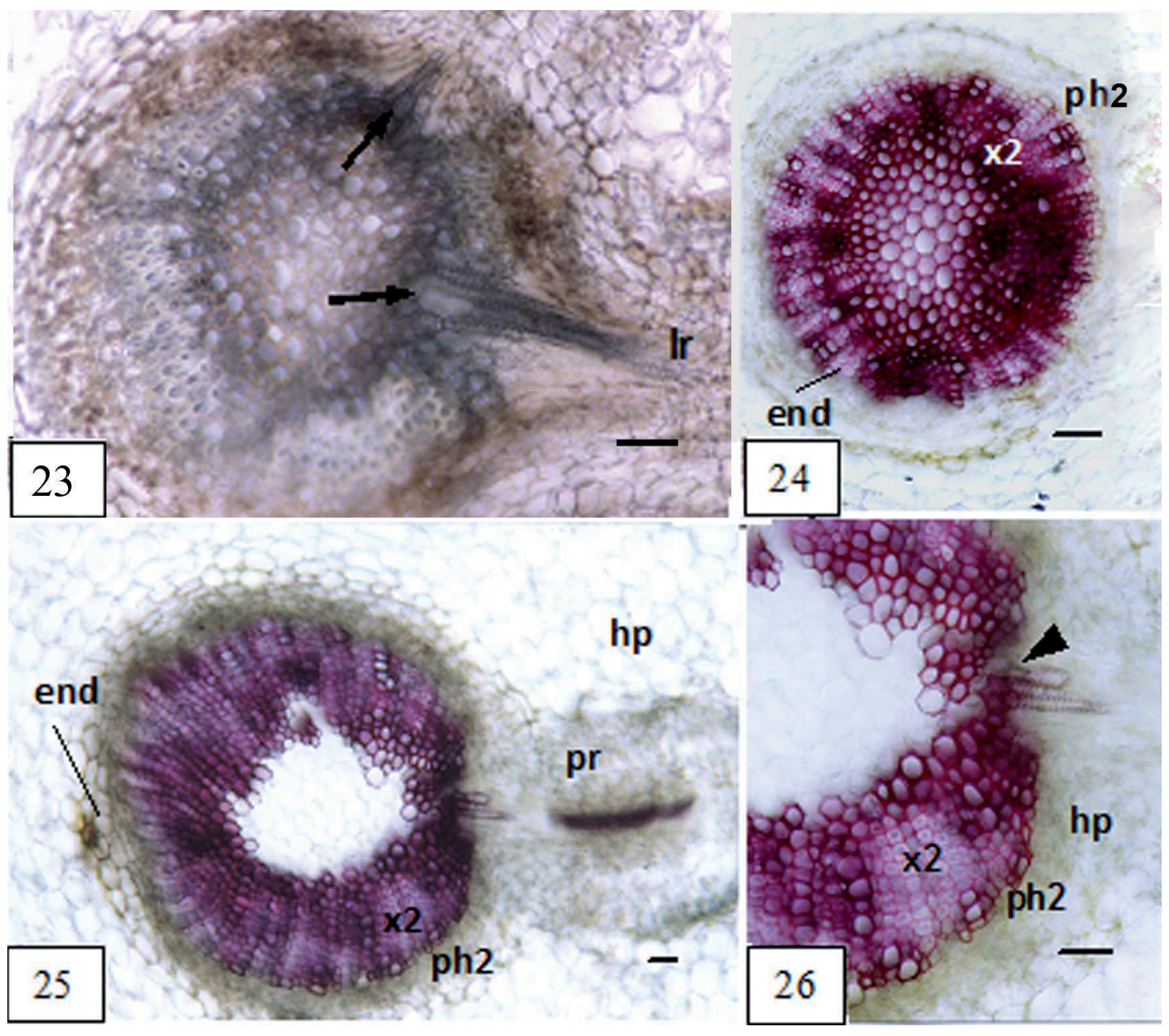

Figures 23-26. Anatomical aspects of the hypocotyl-root of Byrsonima basiloba seedling after reaction with Phloroglucinol. 23. General aspect at $3.5 \mathrm{~cm}$ above the apex showing initial secondary growth in roots (arrows). 24. Organization of the vascular cylinder at $0.2 \mathrm{~cm}$ above the region shown in Figure 23 where the poles of primary xylem cannot be distinguished anymore. Secondary xylem and secondary phloem in differentiation push out the endodermal cells. 25. Oblique root-stem transition region (xylopodium) showing the intersection between the hypocotyl and the principal root. 26. Detail of the Figure 25 showing vessel elements of principal root connected to the secondary xylem of hypocotyl (arrowheads). end: endodermis; hp: hypocotyl; lr: lateral root; pr: principal root; ph2: secondary phloem; $\mathrm{x} 2$ : secondary xylem. Scale bars $=50 \mu \mathrm{m}$.

Figuras 23-26. Aspectos anatómicos del hipocotilo-raíz de la plántula Byrsonima basiloba después de la reacción con Floroglucinol. 23. Aspecto general a $3,5 \mathrm{~cm}$ por encima del ápice de la raíz que muestra el crecimiento secundario inicial en raíces (flechas). 24. Organización del cilindro vascular a $0,2 \mathrm{~cm}$ por encima de la región que se muestran en la Figura 23, donde los polos de xilema primario no se pueden distinguir más. Xilema y floema secundario en la diferenciación empujan a las células del endodermo. 25. Región oblicua de transición raíz-tallo (xylopodium) que muestra la intersección entre el hipocotilo y la raíz principal. 26. Detalle de la Figura 25 que muestra elementos de vaso de la raíz principal conectado a la xilema secundaria del hipocotilo (puntas de flecha). end: endodermos; hp: hipocotilo; lr: raíz lateral; pr: raíz principal; ph2: floema secundario; x2: xilema secundario. La barra de escala $=50 \mu \mathrm{m}$. 
The root connection to the hypocotyl was oblique (Fig. 14), and had a thickened region due to the increase in the number of cell layers on one side of the hypocotyl cortex. Therefore, the vascular system was eccentric in this region (Fig. 27 and 28). In addition, at this region the conducting tissue already presented a secondary growth, although the pericycle and the pith, both composed of parenchyma cells, were clearly visible (Fig. 28). The periderm had just begun to differentiate that originated from outer cells layers of the cortex (Fig. 28). The cotyledonary traces and gaps could be seen in this region (Fig. 28-30).
Close to the cotyledonary node the vascular bundle became centralized (Fig. 29 and 30). Although the cotyledons were visually opposite (Fig. 14), anatomically, they were not inserted at the same level. The cotyledonary traces revealed that the insertion point of both cotyledons differed a few millimeters from each other (Fig. 29 and 30). The cotyledonary basis was adnate, which gradually separated from the stem (Fig. 29 and 30). The epidermis of the stem had abundant trichomes (Fig. 29-30).
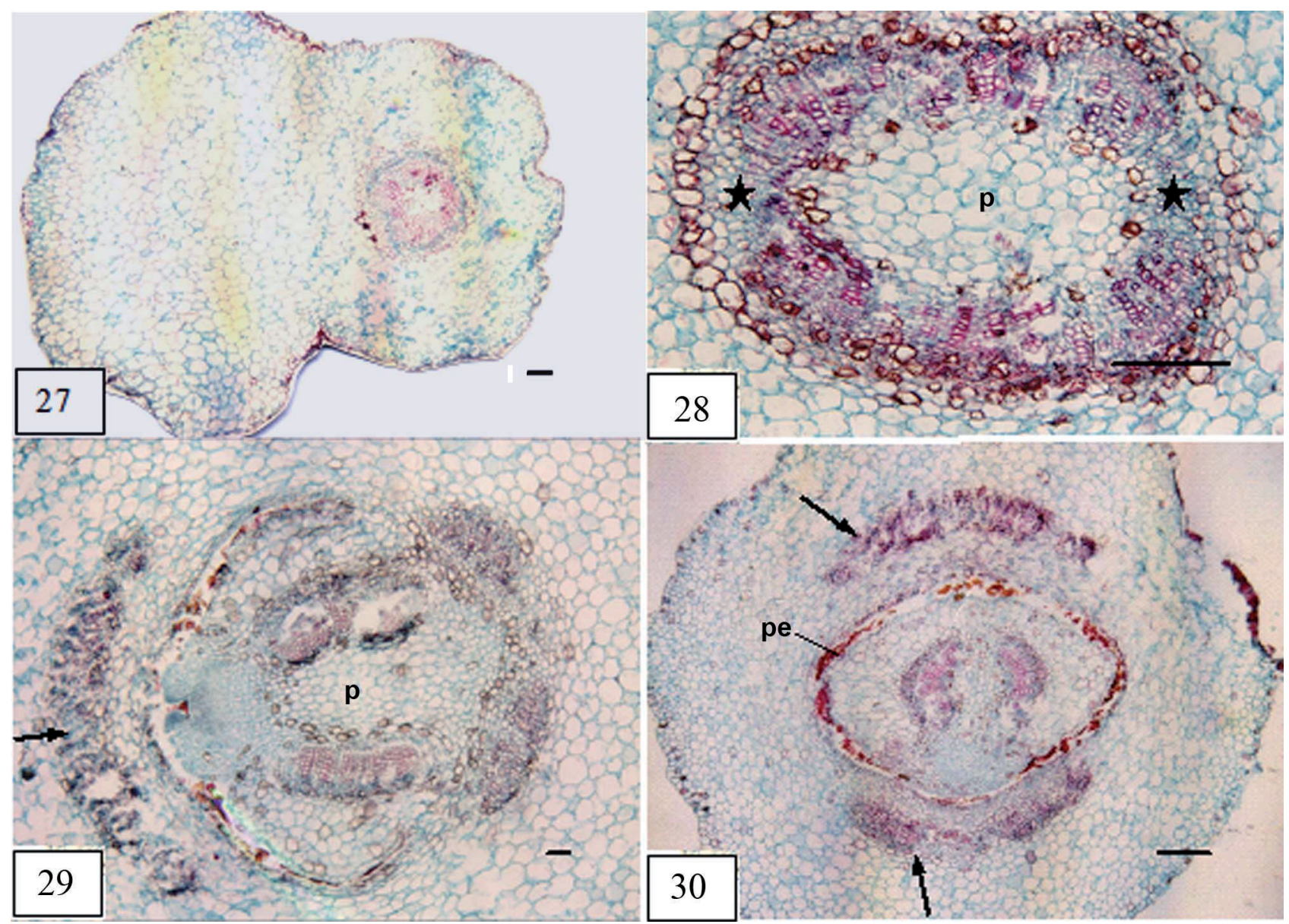

Figures 27-30. Anatomical aspects of Byrsonima basiloba hypocotyl. 27. General view above the base of the hypocotyl, showing the periderm, cortex, vascular tissues, pith and a lateral overgrown region composed of parenchyma cells. 28. Detail of the vascular cylinder showing an initial secondary growth. It is still possible to see the pith, pericycle, the endodermis and the cortex. The vascular tissue is interrupted by the cotyledonary gaps (star). 29. General view of the cotyledonary node showing the cotyledonary traces (arrow) as well as leaf gaps. 30. General view of the cotyledonary node above the previous figure showing two leaf traces (arrows). Note that the insertion points of the cotyledons are uneven. p: pith; pe: pericycle. Scale bars $=100 \mu \mathrm{m}$.

Figuras 27-30. Aspectos anatómicos del hipocotilo de Byrsonima basiloba. 27. Vista general por encima de la base del hipocótilo, que muestra la peridermis, corteza, tejidos vasculares, médula y una región lateral hipertrofiada, compuesta de células de parénquima. 28. Detalle del cilindro vascular que muestra un crecimiento secundario inicial. Todavía es posible ver la médula, periciclo, la endodermis y la corteza. El tejido vascular es interrumpido por los haces de los cotiledones (estrella). 29. Vista general del nudo cotiledonar que muestra los haces de los cotiledones (flecha), así como las lagunas de las hojas. 30. Vista general del nudo cotiledonar por encima de la figura anterior muestra dos haces de hojas (flechas). Tenga en cuenta que los puntos de inserción de los cotiledones son desiguales. p: médula; pe: periciclo. La barra de escala $=100 \mu \mathrm{m}$. 
The cotyledons and the eophylls (Fig. 31-35) presented a midrib and two parallel veins on the margins of the blade. In both cases, the vascular bundle of the midrib was organized in a semicircle with the phloem placed on the abaxial side of the leaf, which characterized collateral bundle (Fig. 31 and 34). Moreover, the mesophylls of cotyledons and eophylls were dorsiventral, with a single-layered palisade parenchyma cells and the spongy parenchyma on the abaxial side (Fig. 32-33). The leaf margins were bent down with mesophyll with three layers of cells (Fig. 33).
The epidermis was uniseriate and amphistomatic whose cells had thin and slightly sinuous walls (Fig. 32-34). The stomata were paracytic or anomocytic, at the same level of the epidermis, and with a higher density on the abaxial surface (Fig. 33 and 35). A thin lipidic cuticle covered the epidermis. Malpighiaceae trichomes covered both faces of eophyll epidermis, with a higher density on the abaxial face (Fig. 35). Idioblasts containing druses were seen in the veins and the mesophyll.

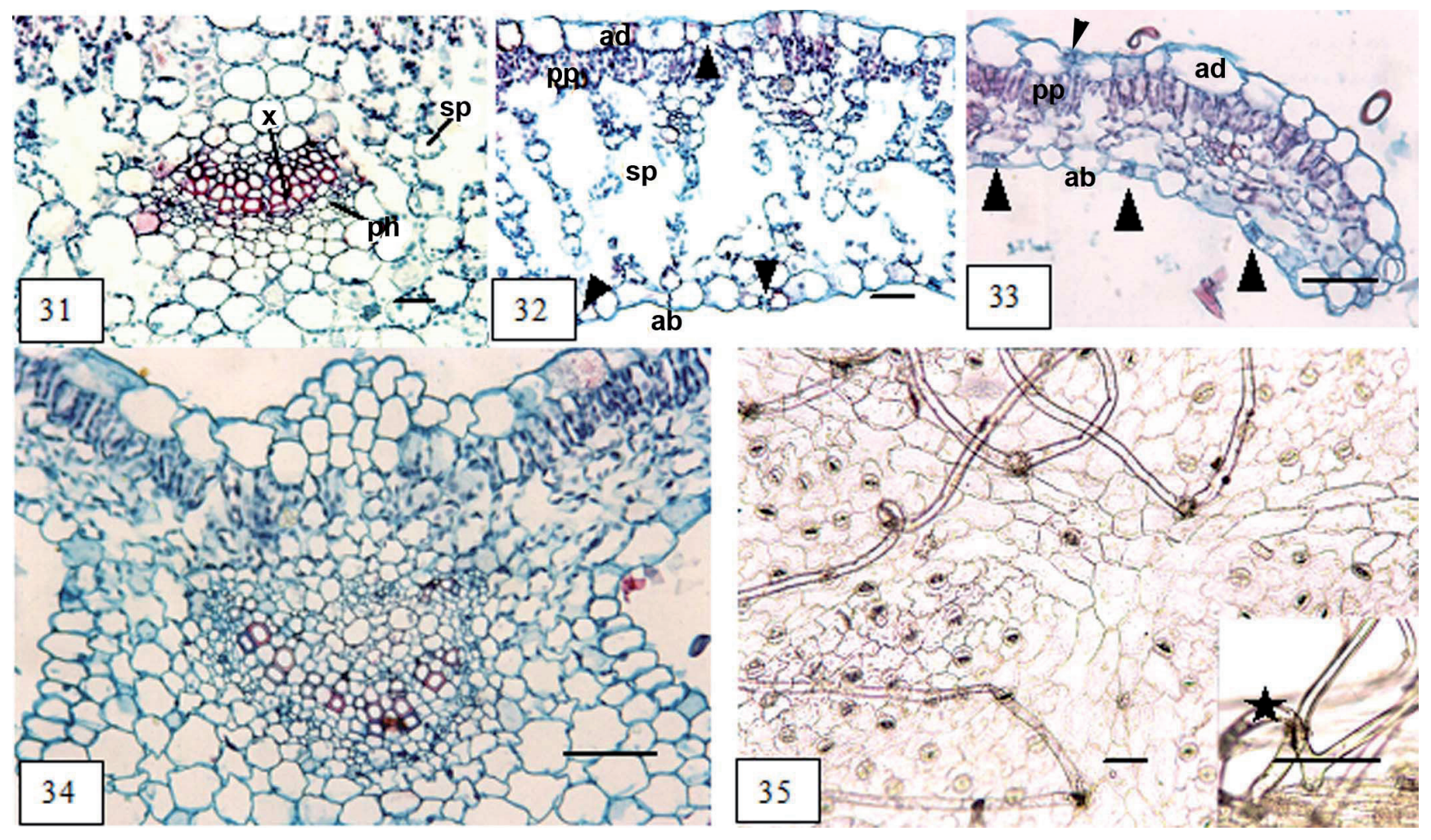

Figures 31-35. Morpho-anatomical aspects of cotyledons and eophylls from two-month old Byrsonima basiloba seedlings. 31. Cotyledon midvein region showing a collateral vascular bundle. Note that the xylem was on the adaxial and the phloem on the abaxial side of the leaf. 32. Transverse section of cotyledon. The cotyledon epidermis was uniseriate, amphistomatic (arrowheads) and the mesophyll was dorsiventral. 33. Detail of the eophyll margin. The mesophyll was dorsiventral and the leaf was amphistomatic (arrowheads). 34. Micrograph showing the midrib of the eophyll with poorly differentiated collateral vascular bundle. The vascular system was a semicircle with the xylem on the adaxial side of the leaf. 35. Paradermal section of the abaxial face of the eophyll with abundant Malpighiaceae trichomes on the veins. Inset: Detail of Malpighiaceae trichomes (star). ab: abaxial epidermis; ad: adaxial epidermis; ph: phloem; pp: palisade parenchyma; sp: spongy parenchyma; $x$ : xylem. Scale bars $=50 \mu \mathrm{m}$.

Figuras 31-35. Aspectos morfo-anatómicos de los cotiledones y eofilos de Byrsonima basiloba plántulas de dos meses de edad. 31 . Región de la vena media del cotiledón que muestra un haz vascular colateral. Tenga en cuenta que el xilema fue el de adaxial y el floema en la abaxial. 32. Sección transversal de los cotiledones. La epidermis del cotiledones fue uniseriados, anfiestomáticas (puntas de flecha) y el mesófilo fue dorsiventral. 33. Detalle del margen del eofilo. El mesófilo fue dorsiventral y la hoja fue anfiestomáticas (puntas de flecha). 34. Microfotografía de la vena central del eofilo con el paquete vascular colateral pobremente diferenciado. El sistema vascular era un semicírculo con el xilema en el lado adaxial de la hoja. 35. Paradermal sección de la face abaxial del eofilo con abundantes tricomas Malpigiáceas en las costillas. Recuadro: Detalle de Malpigiáceas tricomas (estrella). ab: epidermis abaxial; ad: epidermis adaxial; ph: floema; pp: parénquima en empalizada; sp: parénquima esponjoso; x: xilema. La barra de escala $=50 \mu \mathrm{m}$. 
The shoot apex (Fig. 36-39) was flat with reduced diameter. The region of the promeristem was made of a tunica containing two layers of cells and a four-cell layered corpus, with large nuclei (Fig. 36-37). The cells of the procambium were cylindrical, with nuclei in the center of the cell, while the cells of the ground meristem presented a smaller proportion of nucleus/cytoplasm (Fig.
36-37). The protoderm was covered by long trichomes while the procambium cells remained undifferentiated. In the differentiating zone, pith cells presented large vacuoles with druses (Fig. 38 and 39). In this region, the procambium cells were partially differentiated with vessel elements with helical thickening (Fig. 39).

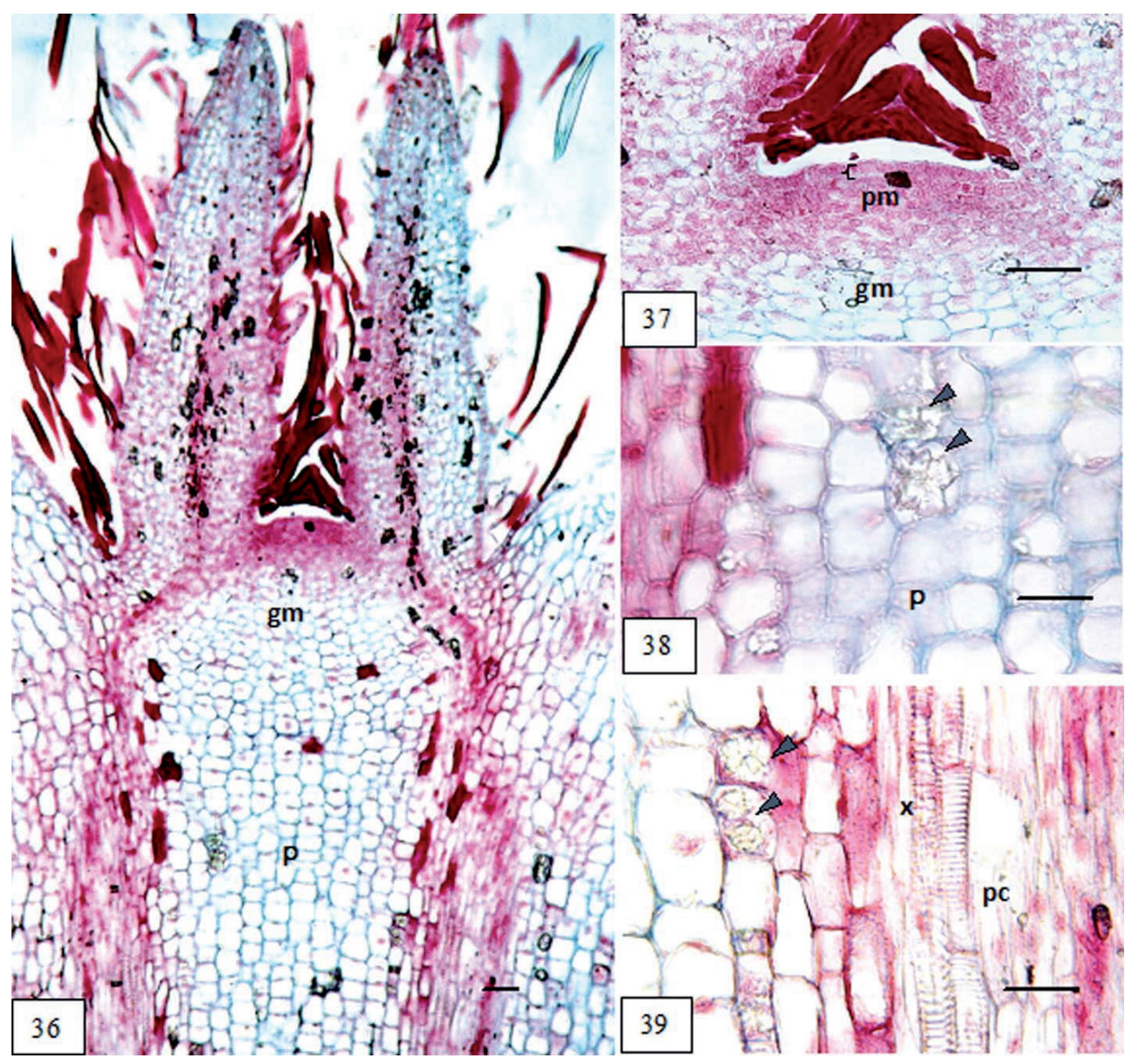

Figures 36-39. Anatomical aspects of the shoot apical meristem of Byrsonima basiloba seedlings. 36. General view of B. basiloba shoot apex showing the elongation and differentiation zone, leaf primordia with long trichomes, cortex, pith and differentiating vascular system. 37. Micrograph of the shoot apical meristem. 38. Detail of a region near the pith with idioblasts containing druses (arrowheads). 39. Procambium region showing differentiating vessel elements as well as cells with druse (arrowheads). gm: ground meristem; p: pith; pc: procambium; pm: promeristem; x: primary xylem. Scale bars: $36=50 \mu \mathrm{m} ; 37-39=20 \mu \mathrm{m}$.

Figuras 36-39. Aspectos anatómicos del meristemo apical de las plântulas de Byrsonima basiloba. 36. Vista general del meristemo apical de $B$. basiloba que muestra el alargamiento y la zona de la diferenciación, los primordios de la hoja de tricomas largos, corteza, médula y la diferenciación del sistema vascular. 37. Micrografía de los meristemos apicales rodaje. 38. Detalle de una región cercana a la médula con idioblastos contiene drusas (puntas de flecha). 39. Procambium región que muestra la diferenciación del elementos de vasos, así como células con drusas (puntas de flecha). gm: meristemo fundamental; p: médula; pc: procambium; pm: promeristemo; x: xilema primario. La barra de escala: $36=50 \mu \mathrm{m} ; 37-39=20 \mu \mathrm{m}$. 


\section{DISCUSSION}

Normally, fruit and seeds present small phenotypic plasticity. Therefore, Byrsonima typically presents a drupe fruit with a single pyrene divided into three loci (Anderson 1977, Barroso et al. 1999). Nevertheless, the crested endocarp observed in B. basiloba with a shape of three-pointed star suture had not yet been described in other species of the genus. Therefore, this feature has a significant taxonomic impact for the identification of this species in the field.

The anatomical structure of B. basiloba endocarp confers, at the same time, antagonistic properties: rigidity, lightness, and insulation. The large lumens of the sclerified cells and the irregular distribution of the cells not only reduce the density of the tissue but also help to insulate the seed. Consistently, the endocarp of $B$. intermedia A. Juss. is also composed of many layers of sclereids, which in this case, were elongated in the longitudinal sense of the fruit (Souto \& Oliveira 2005). These findings can be related to the ecological strategies of seed dispersal. For instance, the sclerified endocarp of these species may insulate and protect the seed against the frequent fires in Cerrado, and simultaneously, the high temperatures can lead to the fracture of the endocarp, and thereby, to the release of the seed.

According to Boesewinkel \& Bouman (1984), the reduction of the seed coat had been systematically observed in seeds with woody, indehiscent pericarps. In such cases the protective role of the seed is carried out by the pyrene. In Cerrado, it is common that the plants present hard sclerified and water impermeable seed coats, which must be removed by mechanical fracture or fire to allow the seed to imbibe and germinate (Palhares 2004). Furthermore, B. basiloba seeds are not dormant. However, the hard endocarp may be a barrier for water absorption; hence, it must be broken to allow seed germination.

Malpighiaceae seeds usually do not present endosperm. Rather, they have a thin brownish coat and foliaceous cotyledons (Anderson 1990, Barroso et al. 1999). This exalbuminous aspect is consistent with the presence of well-developed cotyledons, rich in reserve, which is a characteristic of this family (Subbarao 1939, Giulietti 1971, Lorenzo 1981; Souto \& Oliveira 2005). The anatomical analysis of $B$. basiloba seeds showed the accumulation of proteins and lipids in the cotyledon and tegument. Malpighia glabra L. also accumulate these compounds in the same organs (Nacif et al. 1996). On the other hand, B. intermedia (Souto \& Oliveira 2005), Banisteriopsis and Diplopterys pubipetala (A.Juss.) W.R. Anderson \& C. Davis (Souto \& Oliveira 2008) have as reserve substances lipids and starch. Seeds of Smilax polyantha Griseb., also a Cerrado species, store proteins and lipids (Martins et al. 2012). However, during germination process, $S$. polyantha synthesizes and accumulates starch in the cotyledons, which takes place concomitantly with the thinning of the endosperm cell walls (Martins et al. 2012). This fact indicated that, during germination, cell wall polysaccharides may be used for starch synthesis in this plant. Furthermore, according to the authors, $S$. polyantha do not use the seed protein content during germination. This process may not be the case of $B$. basiloba. Although neither starch nor protein contents were not analyzed, after germination, more precisely around the $60^{\text {th }}$ day of cultivation, there was no visual of granules of any sort in the cotyledonary cells (data not shown).

According to Barroso et al. (1999), the embryo of the Byrsonima was axial and placed in the central region of the seed. Besides, these authors postulated that the hypocotylroot system has no clear delimitation and the cotyledons are circinate and curled up in a spiral shape. Furthermore, Malpighiaceae embryos can be morphologically variable as seen in Malpighia glabra, Lophanthera lactescens Ducke and B. intermedia, which has straight, or folded, or coiled embryos (Nacif et al. 1996, Paoli 1997, Souto \& Oliveira 2005). In B. basiloba embryos, although subtle, it was possible to differentiate the shoot/root promeristem, protoderm, procambium and ground meristem. Moreover, the data presented here showed that it was possible to differentiate between the hypocotyl and root transition zone. The Figure 14 clearly shows the existence of a small constriction, which is a morphological milestone to distinguish hypocotyl from root system (Souza et al. 2009).

In $B$. basiloba seedlings were noticeable that beside the promeristem, the in the leaf primordia, there was an epidermis with trichomes and a procambium with a partially differentiated vascular system. It appears that the differentiation of the tissues in this species occurs early. This fact certainly helps seedling establishment after germination.

Araújo (1994) and Oliveira (2001) stated that the morphology of cotyledons may vary among species of the same genus, which could facilitate the identification of seedlings a given species. Hence, as a comparison, the cotyledons of B. coriaceae (Sw.) DC. are lanceolate (Duke 1969), while $B$. basiloba have cotyledons oblong with a decurrent basis. Moreover, B. basiloba cotyledons remained attached to the seedling for more than six months and became photosynthetically active. As a result, the morphoanatomical structure of the cotyledons after two months was very similar to the eophylls. These changes in B. basiloba cotyledons after the germination may have taxonomic applications, helping to recognize seedlings in the field.

In the Malpighiaceae there are hypostomatic and amphistomatic species, and, the paracytic stoma is the most frequent in this family (Beiguelman 1962, Giulietti 1971, Mamede 1993). The ecological advantages of amphistomy or hypostomy have not yet been fully understood (Palhares \& Zaidan 2010, Palhares et al. 2011). Apparently, amphistomy occurs most frequently in sunny environments 
that are neither very dry nor very humid, such as the Cerrado. However, in similar ecosystems are found both hypostomatic and amphistomatic species within the same genus, which has brought new issues to be discussed about this topic (Palhares et al. 2011). With respect to eophylls, in $B$. basiloba, they have similar mesophyll organization as leaves from adult plants. Nevertheless, B. basiloba eophylls were amphistomatic while the adult leaves had stomata only on the abaxial side (Silveira, personal communication).

The apical bud of B. basiloba was exposed before the completion of eophyll elongation. Besides, densely haired eophylls are a common characteristic in Malpighiaceae (Araújo et al. 2010). In the current studied species, long trichomes were also seen in the leaf primordia and druses in the mesophyll. The function of trichomes in leaf primordia is to protect the apical bud. The trichome, generally, also contains phenolic compounds that protect against plagues and diseases, delimiting the development of pathogenic micro-organisms and predation by herbivores (Taiz \& Zeiger 1998).

In the root-stem transition zone, which originated the xylopodium seen in adult plants, did not show any change in color and was oblique to the stem axis. Typically, during the xylopodium ontogenesis, the thickening of parenchymatic tissue occurs due to improvement in cell numbers and volume (Paviani 1987, Vilhalva \& Appezzato-da-Glória 2006). This data is consistent with the findings of B. basiloba xylopodium development. Therefore, this fact has obvious applications for the propagation of this species. The natural ability of xylopodia to form new buds gives the root-stem transition zone an enormous potential to be used as explant source for the production of new plants, in nature as well as through agricultural techniques (Silveira et al., 2013b)

In conclusion, the anatomical description presented here can help with taxonomic identification of the species as well as to subsidize in vitro cultivation protocols. It is important to know the normal morpho-anatomical structure of seedlings to facilitate their recognition in the field, as well as determine the degree of normality of plants produced by in vitro procedures.

\section{ACKNOWLEDGEMENTS}

We thank the Indian company Content Concepts for English review. To Camilo Manchola for the Spanish review, as well as the Coordination for the Improvement of Higher Level Personnel (CAPES), the Brazilian Council of Research (CNPq) for the financial support of this research.

\section{REFERENCES}

Almeida, S.P., C.E.B. ProençA, S.M. Sano \& J.F. Ribeiro. 1998.
Cerrado: Espécies Vegetais Úteis. EMBRAPA-CPAC, Brasília. 388 pp.

Anderson, W.R. 1977. Byrsonimoideae, a new subfamily of the Malpighiaceae. Leandra 6-7: 5-18.

Anderson, W.R. 1990. The origin of the Malpighiaceae: the evidence from morphology. Memoirs of The New York Botanical Garden 64: 210-224.

ARAúJo, A.R.B. 1994. Morfologia de frutos, sementes e plântulas, tipo e aspectos da germinação de algumas espécies de Malpighiaceae. MSc Dissertation, University of Campinas. $68 \mathrm{pp}$.

Araújo, J.S., A.A. Azevedo, L.C. Silva \& R.M.S. Meira. 2010. Leaf anatomy as an additional taxonomy tool for 16 species of Malpighiaceae found in the Cerrado area. Plant Systematics and Evolution 286: 117-131.

BArros, M.A.G. 1992. Fenologia da floração, estratégias reprodutivas e polinização de espécies simpátricas do gênero Byrsonima Rich (Malpighiaceae). Revista Brasileira de Biologia 52: 343-353.

Barroso, G.M., M.P. Morim, A.L. Peixoto \& C.L.F. Ichaso. 1999. Frutos e sementes - Morfologia à sistemática de dicotiledôneas. Editora UFV, Viçosa. 186 pp.

Beiguelman, B. 1962. Considerações sobre a morfologia dos estomas de Annona coriacea Mart., Byrsonima coccolobifolia Kunth., Erythroxylum suberosum St. Hil. e Ouratea spectabilis (Mart.) Engl. Revista Brasileira de Biologia 22(2):115-124.

Boesewinkel, F.D. \& F. Bouman. 1984. The seed: structure. In: B.M. Johri (ed.), Embryology of Angiosperms, pp. 567610, Springer-Verlag Berlin.

Duke, J.A. 1965. Keys for the identification of seedlings of some prominent woody species in eight forest types in Puerto Rico. Annals of the Missouri Botanical Garden 52(3): 314350 .

Duke, J.A. 1969. On tropical tree seedlings - I. Seeds, seedlings, systems, and systematics. Annals of the Missouri Botanical Garden 56(2): 125-161.

Giulietti, A.M. 1971. Byrsonima do Distrito Federal. In: M.G. Ferri (ed.), III Simpósio do Cerrado, pp. 113-149. Edgard Blücher São Paulo.

Johansen, D.A. 1940. Plant microtechnique. McGraw-Hill Book Company Inc., New York. 523 pp.

LoREnzo, E. 1981. Sobre la inflorescencia, morfologia floral y embriologia de Janusia guaranitica (Malpighiaceae). Kurtziana 14: 101-124.

Mamede, M.C.H. 1993. Anatomia dos órgãos vegetativos de Camarea (Malpighiaceae). Acta Botanica Brasilica 7(1): 3-19.

Martendal, C.O., M.M. Bernardino, F.D. Pereira, F.G. Silva, C.C.E. Menezes \& A.C. Hara. 2013. In vitro cultivation of zygotic embryos from murici (Byrsonima cydoniifolia A. Juss.): establishment, disinfection and germination. Acta Scientiarum 35(2): 221-229.

Martins, A.R., S.M. Carmello-Guerreiro, M.S. Buckeridge, C.O. Silva \& B. Appezzato-Da-GlóRia. 2012. Seed ontogeny and endosperm chemical analysis in Smilax polyantha (Smilacaceae). Australian Journal of Botany 60(8): 693699.

NACIF, S.R., M.C. Guardia \& P.L.R. Moraes. 1996. Morfologia e anatomia das sementes de acerola (Malpighia glabra L. - 
Malpighiaceae). Revista Ceres 43: 597-610.

Oliveira, D.M.T. 2001. Morfologia comparada de plântulas e plantas jovens de leguminosas arbóreas nativas: espécies de Phaseoleae, Sophoreae, Swartzieae e Tephrosieae. Revista Brasileira de Botânica 24(1): 85-97.

Palhares, D. 2004. Proposta de aula prática sobre a germinação de Vellozia flavicans Mart. ex Schult (Velloziaceae). Lecta 22(1/2): 7-9.

Palhares, D., A.C. Franco \& L.B.P. Zaidan. 2011. Photosynthetic responses of Smilax goyazana. Phyton 51(2): 115-132.

Palhares, D. \& L.B.P. ZAidAn. 2010. A brief review on leaf anatomy of plants with certain peculiar modes of photosynthesis. Revista Biociências 16(1): 7-15

Paoli, A.A.S. 1997. Morfo-anatomia de frutos e sementes de Lophantera lactescens Ducke (Malpighiaceae). Revista Brasileira de Sementes 19: 238-244.

Paviani, T.I. 1987. Anatomia do desenvolvimento do xilopódio de Brasilia sickii G.M. Barroso. Ciência e Cultura 39: 399405.

Silva, L.C., R. Paiva, D.P. Silva, S. Barbosa, R. Herrera, L.C. Davide \& P.D. Paiva. 2012. Characterization of pro-embryogenic calli and somatic embryogenesis of Byrsonima intermedia A. Juss. Journal of Agricultural and Science Technology A 2(8A): 962-970.

Silveira, C.E.S., W. Fukuda, T. Miranda, D. Palhares \& L.A.R. Pereira. 2013a. Jacaranda ulei Bureau and K. Schum. (Bignoniaceae): in vitro seedling and developmental study as a contribution towards the domestication of this medicinal Brazilian savannah species. Journal of Pharmacognosy and Phytochemistry 2(4): 85-89.
Silveira, C.E.S., D. Palhares, L.A.R. Pereira, K. Pereira \& F. SiLVA. 2013b. Strategies of plant establishment of two Cerrado species: Byrsonima basiloba Juss. (Malpighiaceae) and Eugenia dysenterica Mart. ex DC. (Myrtaceae). Plant Species Biology 28(2): 130-137.

Souto, L.S. \& D.M.T. Oliveira. 2005. Morfoanatomia e ontogênese do fruto e semente de Byrsonima intermedia A. Juss. (Malpighiaceae). Revista Brasileira de Botânica 28: 697-712.

Souto, L.S. \& D.M.T. Oliveira. 2008. Morfoanatomia e ontogênese das sementes de espécies de Banisteriopsis C.B. Robinson e Diplopterys A. Juss. (Malpighiaceae). Acta Botanica Brasilica 22(3): 733-740.

Souza, L.A., I.S. Moscheta, K.S.M. Mourão, A.L.M. Albiero, D.R. Montanher \& A.A.S. Paoli. 2009. Morphology of seedling and of tirodendro. In: L.A. Souza (org.). Seeds and Seedlings-Germination, Structure and Adaptation. Toda Palavra Ed., Ponta Grossa, Paraná. pp. 119-190.

Subbarao, A.M. 1939. Studies in the Malpighiaceae: I. Embryosac development and embryogeny in the genera Hiptage, Banisteria and Stigmaphyllum. Journal of the Indian Botanical Society 18: 146-156.

Taiz, L. \& E. Zeiger. 1998. Plant Defenses: Surface Protectants and Secondary Metabolites. In: L. Taiz \& E. Zeiger (orgs.). Plant Physiology. $2^{\text {nd }}$ ed. pp. 347-376. Sinauer Associates Inc. Publishers, Sunderland.

Vilhalva, D. \& B. AppeZZATo-DA-GlóRIA. 2006. Morfo-anatomia do sistema subterrâneo de Calea verticillata (Klatt) Pruski e Isostigma megapotamicum (Spreng.) Sherff (Asteraceae). Revista Brasileira de Botânica 29(1): 39-47.

Recibido: 29.10 .15

Aceptado: 09.08.16 